\title{
A Low-Cost Open Source Device for Cell Microencapsulation
}

\author{
Miriam Salles Pereira ${ }^{1,2}$, Liana Monteiro da Fonseca Cardoso ${ }^{1}\left(\mathbb{D}\right.$, Tatiane Barreto da Silva ${ }^{1}$, \\ Ayla Josma Teixeira ${ }^{1}$, Saul Eliahú Mizrahi ${ }^{3}$, Gabriel Schonwandt Mendes Ferreira ${ }^{3}$, \\ Fabio Moyses Lins Dantas ${ }^{3}$ (i), Vinicius Cotta-de-Almeida ${ }^{4,5}$ and Luiz Anastacio Alves ${ }^{1, *}$ \\ 1 Laboratory of Cellular Communication, Oswaldo Cruz Institute, Oswaldo Cruz Foundation, \\ 4365 Manguinhos, Rio de Janeiro 21045-900, Brazil; msmakeba@gmail.com (M.S.P.); \\ lianamfc@gmail.com (L.M.d.F.C.); tatiane.barreto321@gmail.com (T.B.d.S.); aylajosma02@gmail.com (A.J.T.) \\ 2 Volta Redonda University Center-UniFOA, Av. Paulo Erlei Alves Abrantes, 1325-Três Poços, \\ Volta Redonda 27240-560, Brazil \\ 3 National Institute of Technology-INT, Rio de Janeiro Av. Venezuela, 82-Saúde, Rio de Janeiro 20081-312, \\ Brazil; saul.mizrahi@int.gov.br (S.E.M.); gabriel.mendes@int.gov.br (G.S.M.F.); \\ fabio.dantas@int.gov.br (F.M.L.D.) \\ 4 Laboratory on Thymus Research, Oswaldo Cruz Institute, Oswaldo Cruz Foundation, 4365 Manguinhos, \\ Rio de Janeiro 21045-900, Brazil; vca@ioc.fiocruz.br \\ 5 National Institute of Science and Technology on Neuroimmunomodulation (INCT-NIM), \\ Oswaldo Cruz Institute, Oswaldo Cruz Foundation, 4365 Manguinhos, Rio de Janeiro 21045-900, Brazil \\ * Correspondence: alveslaa30@gmail.com; Tel.: +55-21-2562-1841; Fax: +55-21-2562-1816
}

Received: 28 July 2020; Accepted: 1 September 2020; Published: 11 November 2020

check for updates

\begin{abstract}
Microencapsulation is a widely studied cell therapy and tissue bioengineering technique, since it is capable of creating an immune-privileged site, protecting encapsulated cells from the host immune system. Several polymers have been tested, but sodium alginate is in widespread use for cell encapsulation applications, due to its low toxicity and easy manipulation. Different cell encapsulation methods have been described in the literature using pressure differences or electrostatic changes with high cost commercial devices (about 30,000 US dollars). Herein, a low-cost device (about 100 US dollars) that can be created by commercial syringes or 3D printer devices has been developed. The capsules, whose diameter is around $500 \mu \mathrm{m}$ and can decrease or increase according to the pressure applied to the system, is able to maintain cells viable and functional. The hydrogel porosity of the capsule indicates that the immune system is not capable of destroying host cells, demonstrating that new studies can be developed for cell therapy at low cost with microencapsulation production. This device may aid pre-clinical and clinical projects in low- and middle-income countries and is lined up with open source equipment devices.
\end{abstract}

Keywords: alginate; 3D printer; microencapsulation; cell transplantation; cell therapy

\section{Introduction}

Currently, health technology and research equipment are crucial to improve medical care and pre-clinical experiments in low- and middle-income countries. In this context, several groups worldwide have developed technology using the concept of "open source equipment and medical devices". This concept has been essential for the development of the software industry [1-3]. In keeping with these ideas, we have developed a low cost cell encapsulation device that can be easily constructed and can be used for cellular transplantation of different cell types.

Cell microencapsulation technology has been investigated and studied for over 36 years. This proposal was first described in 1964, when Chang microencapsulated mammalian erythrocytes in 
nylon based on the concept of developing artificial cells [4]. However, it was first used therapeutically in 1980, when Lim and Sun microencapsulated pancreatic beta cells in alginate in order to treat diabetic rats [5]. Recent progress in the field has resulted in biodegradable scaffolds that are able to retain and release cell contents in different anatomical locations. The microencapsulation process consists in the involvement of particles or biological materials, such as cells, at least one dimension less than $1.000 \mu \mathrm{m}$. Cells are microencapsulated when entrapped within a semipermeable polymer matrix (microsphere, microbead) at the micrometer scale [6,7]. The micrometer scale of microencapsulated cell implants is within the diffusion limits of many small molecules, such as glucose, amino acids, hormones, neurotransmitters and cytokines, while the pores of the encapsulating polymer are large enough to permit their influx. In addition, it is also possible to release small substances produced by microencapsulated cells as hormones and metabolites [7]. Another important point regarding microcapsule manufacture is the ability to create porosities smaller than the size that would allow a contact with components of the immune system, such as T cells, macrophages, antibodies and complement proteins, creating a barrier for interactions with surface antigens of microencapsulated cells [8]. A reduction in capsule size is considered to be one of the most important objectives in the microcapsules microenvironment, while allowing for a bidirectional nutrient, oxygen, and waste diffusion [9]. In addition, smaller capsules are more biocompatible than larger ones [10].

With the advent of cell therapy and tissue bioengineering, it became possible to treat lesions in various tissues present in pathologies and degenerative processes, which were previously untreatable. Thus, living cells have become an important tool in the advancement of therapeutic strategies with wide clinical applications [11]. However, the shortage of human organs that can be used as sources for obtaining target cells is an obstacle that has yet to be overcome for the success of some of these therapeutic approaches. In this context, microencapsulation is a widely studied technique for the accomplishment of cellular therapies, since the formed membrane allows for gas and vital nutrient permeability for cell maintenance, which does not activate immune system components, thus favoring its use in cellular transplantation [12]. Microencapsulation also protects cells from possible mechanical lesions, as well as from substances harmful to cellular viability, thus conferring greater survival conditions within the host $[6,13]$.

In addition to application in cell therapies, particle microencapsulation has been studied and used in several areas for the transport of various bioactive compounds, such as drugs, vitamins, peptides, flavorings, dyes, essential oils, nutrients and pesticides [7,13]. Some basic aspects should be considered in the development of microencapsulated systems, such as the nature and stability of the material to be encapsulated, the microencapsulation process in itself, the characteristics of the encapsulating polymer and the product to be obtained.

The current relevance of microencapsulation derives from its use mainly as a therapeutic mechanism for treating a wide range of human diseases, such as diabetes, blood disorders, acute liver failure, spinal cord injury, and several types of cancer. Pancreatic islets, blood cells, hepatocytes, and stem cells are among the many cell types currently used for this strategy [14-18]. For this, different microencapsulation materials are being investigated. Microencapsulation materials comprise natural or synthetic polymers or blends, including collagen, gelatin, fibrin, polyphosphazenes, poly(acrylic acids), poly (methacrylic acids), copolymers of acrylic acid and methacrylic acid, poly(alkylene oxides), poly(vinyl acetate), polyvinylpyrrolidone, polyethylene glycol (PEG), polyethersulfone, polysaccharides such as agarose, cellulose sulfate, chondroitin sulfate, chitosan, hyaluronan, and copolymers, and blends of each $[19,20]$. The most widely researched microencapsulated cells are pancreatic beta cells within alginate/poly-L-lysine-based hydrogel microcapsules, which are currently applied in several studies for diabetes treatment [21-23]. The alginate membrane is a biodegradable polymer, derived from brown algae, and has been used in xenotransplantation procedures to generate protection for the transplanted cells against attack by the immune system, allowing for the diffusion of nutrients, oxygen and metabolic products, in order to maintain cellular physiology. The improvement of this technique may favor the development of therapies without requiring immunosuppressive 
drugs [24-26]. Our group develops a research area focused on the treatment of liver diseases through hepatocyte transplantation. In view of the difficulties of obtaining human cells to perform the therapeutic procedure, as well as to avoid an immune response against the injected cells, we have developed a low cost device for cellular microencapsulation produced in a 3D printer or associated with syringes. Thus, this study describes the encapsulation device mechanism and the formed "membrane" characteristics concerning microcapsule manufacture using sodium alginate.

\section{Materials and Methods}

\subsection{Cell Line}

Human hepatocellular carcinoma cells (HepG2) were maintained following standard mammalian cell culture practices (ATCC, Manassas, VA, USA). The cells were cultured in Roswell Park Memorial Institute medium (RPMI-1640) (Sigma-Aldrich, St. Louis, MO, USA) and supplemented with $10 \%$ fetal bovine serum (FBS) (Gibco Laboratories, Grand Island, NY, USA). They were then incubated at $37^{\circ} \mathrm{C}$ in a $5 \% \mathrm{CO}_{2}$ humidified environment in cell culture dishes until 70-80\% confluency. For the experiments, the cells were trypsinized with a trypsin solution at $0.025 \%$ containing $0.4 \%$ EDTA (ethylene diamine tetraacetic acid) (Sigma-Aldrich, St. Louis, MO, USA).

\subsection{Device}

Two types of devices were created for cellular encapsulation. The first used a long-stay peripheral vein puncture equipment of two different sizes, the best-sized (24G) metal cutting part attached to the polypropylene part of the more calibrated device (16G). A $40 \mathrm{~mm} \times 12 \mathrm{~mm}$ needle is located on the side, which allows $\mathrm{N}_{2}$ to enter, forming a parallel air system, which reduces the diameter of the micro-paste to be formed in the alginate solution. This system is connected to a $1 \mathrm{~mL}$ syringe containing cells diluted in a sodium alginate solution (Figure 1A). The second equipment parts were designed and printed using a 3D printer (Figure S1, Supplementary Materials), in order to improve syringe and needle attachments to the previous system (Figure 1C). The 3D model file is available at an online link: https://drive.google.com/file/d/181ZF6c_oanhCNiYoaxchdh3d7813yQdC/view?usp=sharing.

\subsection{Cell Encapsulation}

To test and optimize the use of the encapsulation device, the hepatocarcinoma HepG2 cell line was used as the biological material to be encapsulated. Cells were cultured at $2 \times 10^{6}$ cells $/ \mathrm{mL}$ in RPMI medium supplemented with 10\% FBS (Gibco Laboratories, Grand Island, NY, USA) and incubated at $37^{\circ} \mathrm{C}$ under a $5 \% \mathrm{CO}_{2}$ atmosphere. After culturing, the cell-formed pellet was resuspended in a HEPES-EDTA buffer $\mathrm{pH} 7.0$ and sodium alginate solution, diluted in $0.9 \% \mathrm{NaCl} \mathrm{pH} 7.0$ at a final 1 to $4 \%$ alginate concentration (ideal concentration, $3 \%$ ) to obtain a minimum cell density of $1 \times 10^{6}$ cells $/ \mathrm{mL}$. Then, the solution was aspirated with a $1 \mathrm{~mL}$ syringe and placed in the encapsulation prototype, coupled to the parallel $\mathrm{N}_{2}$ system at $10 \mathrm{~L} / \mathrm{min}$ to obtain more uniform microcapsules with less than $500 \mu \mathrm{m}$. Microdrops are then formed and fall into a Petri dish containing $0.1,0.5$ and $1.0 \mathrm{M}$ calcium chloride solution at $\mathrm{pH} 7.0$ for microcapsule polymerization. It should be noted that the plates were kept in constant movement, avoiding microcapsule overlap. Subsequently, the microcapsules were washed in RPMI-1640 medium containing 10\% FBS and centrifuged for $3 \mathrm{~min}$ at $1000 \mathrm{rpm}$ at $4{ }^{\circ} \mathrm{C}$. The wash solution was then removed and the capsules were maintained in the culture medium at $37^{\circ} \mathrm{C}$ under a $5 \% \mathrm{CO}_{2}$ atmosphere. 

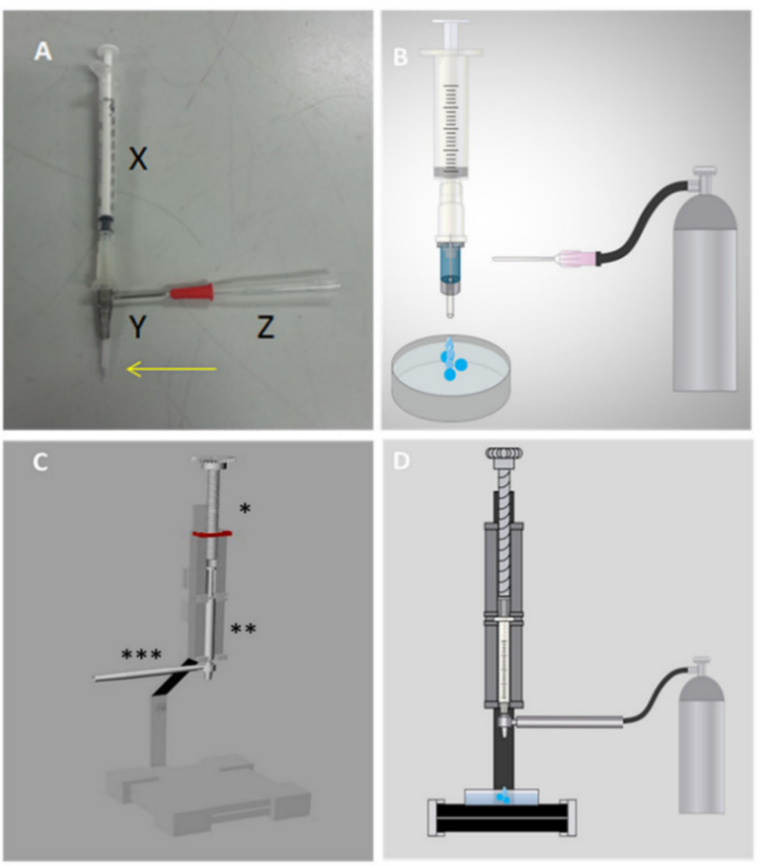

Figure 1. Prototype developed to carry out cellular encapsulation through a parallel air system. (A) First prototype produced with a long-stay peripheral venous puncture device $(X=1 \mathrm{~mL}$ syringe containing the sample in sodium alginate; $\mathrm{Y}=$ long-stay peripheral venous devices $16 \mathrm{G}$ on the outside and $24 \mathrm{G}$ on the inside; = needle connected to the nitrogen gas hose). The arrow highlights the end of the metallic needle $24 \mathrm{G}$ exposed to the environment; (B) first cellular encapsulation prototype coupled to the nitrogen gas bullet; $(\mathbf{C})$ second complete prototype, prepared using a in 3D printer; * part that positions the syringe with the sample to be encapsulated; ${ }^{* *} 1 \mathrm{~mL}$ syringe with sodium alginate solution; *** piece that connects to the parallel air system; (D) second cellular encapsulation prototype coupled to nitrogen gas.

\subsection{Sodium Alginate "Membrane" Porosity}

The morphology and diameter of the sodium alginate microcapsules were evaluated by optical microscopy (Nikon Eclipse TE-2000S, Tokyo, Japan) coupled to 10× and 20× lenses using $2 \mu \mathrm{M} 20$, 70 and $150 \mathrm{KDa}$ FITC-dextran (fluorescein isothiocyanate) (Sigma-Aldrich, St. Louis, MO, USA). Briefly, the microcapsules were incubated with the different molecular weight dyes and evaluated at different time intervals (zero, 24 and $48 \mathrm{~h}$ ) in an in vitro culture. Fluorescence was analyzed by confocal microscopy (Leica DMi8, Wetzlar, Germany).

\subsection{Viability Assessment of Encapsulated Human Hepatocellular Carcinoma Cells (HepG2)}

Fluorescence cell markers were used to determine cell viability. Calcein-AM is a cell-permeant dye that can be used to determine cell viability in most eukaryotic cells. In live cells, non-fluorescent calcein-AM is converted to a green-fluorescent calcein after acetoxymethyl ester hydrolysis by intracellular esterases and confined in the intracellular environment. For this assay, HepG2 cells were incubated with $2 \mu \mathrm{M}$ calcein-AM (Molecular Probes, Eugene, OR, USA) at $37^{\circ} \mathrm{C}$ for $30 \mathrm{~min}$. The cells were then washed in two steps with RPMI medium at $50 \mathrm{~g}$ at $4{ }^{\circ} \mathrm{C}$ for $5 \mathrm{~min}$ and subsequent analyzed by fluorescence microscopy. As the most important factor for evaluating cell viability is to verify plasma membrane integrity, propidium iodide (PI), a fluorescent compound impermeable to the plasma membrane, was used for this purpose. This compound is an intercalating $668.39 \mathrm{Da}$ molecule of paired nucleic acid bases that reaches the intracellular environment after membrane damage. The hepatocytes were incubated with $1 \mu \mathrm{g} / \mathrm{mL}$ PI (Sigma-Aldrich, St. Louis, MO, USA) for $5 \mathrm{~min}$ and washed in two steps with culture medium at $50 \mathrm{~g} 4{ }^{\circ} \mathrm{C}$ for $5 \mathrm{~min}$, followed by three washes with the RPMI medium at $50 \mathrm{~g}$ medium at $4{ }^{\circ} \mathrm{C}$ for $5 \mathrm{~min}$ and analyzed by fluorescence microscopy. 
A similar protocol was performed with YO-PRO1 (Molecular Devices, San José, CA, USA), a 629 kDa fluorescent dye, and trypan blue (873 KDa) (Sigma-Aldrich, Korea) for cell viability assessments.

\subsection{Statistical Analysis}

All numerical results are presented as an arithmetic mean \pm standard deviation (SD). All experiments were performed on at least three different days. The D'Agostino and Pearson normality test was used to assess data normality distribution. If the data followed a Gaussian distribution, an appropriate parametric test was applied; otherwise, an appropriate non-parametric test was applied. The applied tests are specified in the figure legends. $p$ values of 0.05 or less were considered significant. Graphs and statistical analyses were performed using the GraphPad Prism version 5 software (GraphPad Software, San Diego, CA, USA).

\section{Results}

\subsection{Cell Encapsulation Prototype Development}

The prototype was developed using long-stay peripheral venipuncture devices of two different sizes, the smaller metal gauge cutter (size 24G) connected to the syringe containing the sodium alginate solution (Figure $1 \mathrm{~A}(\mathrm{X})$ ). Externally, the polypropylene structure of the larger diameter device (size 16G) was used, securing them and maintaining a longer tip of the metal needle (Figure $1 \mathrm{~A}(\mathrm{Y})$ ). A lateral opening was created for needle coupling, allowing nitrogen to enter, generating a tension on the surface of the formed microcapsule, thus reducing its diameter (Figure $1 \mathrm{~A}(\mathrm{Z})$ ). The microtiter drops into a Petri dish containing a calcium chloride solution, inducing sodium alginate polymerization. Then, the device was perfected, using parts printed by employing a 3D printer. The syringe body of this new device is secured in a longitudinal holder and its plunger is pressed by a threaded part which allows the alginate solution to fall through the turn, as depicted in Figure 1C. The syringe is connected to the metal needle of the previous 24G device, and the larger gauge external 16G device attached to a printed part (Figure S1, Supplementary Materials), which allows the influx of nitrogen, thereby engaging the part to the gas bulb hose.

Some variables were determined for the standardization of the cellular encapsulation, as follows: needle and syringe size to be chosen, nitrogen gas flowmeter pressure, distance between the needle and $16 \mathrm{G}$ calcium chloride solution and sodium alginate and calcium chloride concentrations. Two different gauge needles were tested. The first measured $25 \mathrm{~mm} \times 0.7 \mathrm{~mm}$, whose produced capsules displayed a diameter of more than $2 \mathrm{~mm}$. The second needle measured $14 \mathrm{~mm} \times 0.38 \mathrm{~mm}$ (used for intradermal and subcutaneous administrations in humans) and displayed a diameter ranging from 700 to $1300 \mu \mathrm{m}$. The size of syringes, 1,3 and $5 \mathrm{~mL}$, was also assessed. The capsules in the 3 and $5 \mathrm{~mL}$ syringes presented many deformities, while the $1 \mathrm{~mL}$ syringe displayed higher homogeneity. Thus, a device that allowed for the insertion of a parallel gas system with nitrogen, used in food production and freezing, as well as in cell conservation, was created. The gas flow was tested at 1,3 and $5 \mathrm{~L} / \mathrm{min}$ in a flowmeter, coupled to a gas cylinder, in the first prototype. The $5 \mathrm{~L} / \mathrm{min}$ flow reduced the diameter of and created the most homogeneous microdrops, forming capsules ranging from 500 to $650 \mu \mathrm{m}$. However, when testing the pressure in the second prototype, the capsules were not different from the previous prototype, requiring that the gas flow be increased to $10 \mathrm{~L} / \mathrm{min}$. This flow allowed for formation of capsules smaller than $500 \mu \mathrm{m}$ without any shape change. The sodium alginate microcapsules were evaluated by scanning electron microscopy-SEM (Hitachi TM 3000) fixed on carbon tapes at $5 \mathrm{kV}$, with magnification from $120 \times(A), 150 \times(B)$ and 250× (C). (Figure S2, Supplementary Materials)

Assessment of distance between the needle and the calcium chloride solution indicate that the $10 \mathrm{~cm}$ distance led to larger diameter capsules $(710 \pm 135 \mu \mathrm{m})$, as compared to $20(364 \pm 65 \mu \mathrm{m})$ and $30 \mathrm{~cm}(593 \pm 136 \mu \mathrm{m})$ distances (Figure 2). Moreover, capsules were more homogeneous at $20 \mathrm{~cm}$ distance in height (Figure 2B). However, at $30 \mathrm{~cm}$, loss of material around the Petri dish and varied-sized capsules were noted. Thus, the ideal distance for this type of prototype was set at $20 \mathrm{~cm}$. 

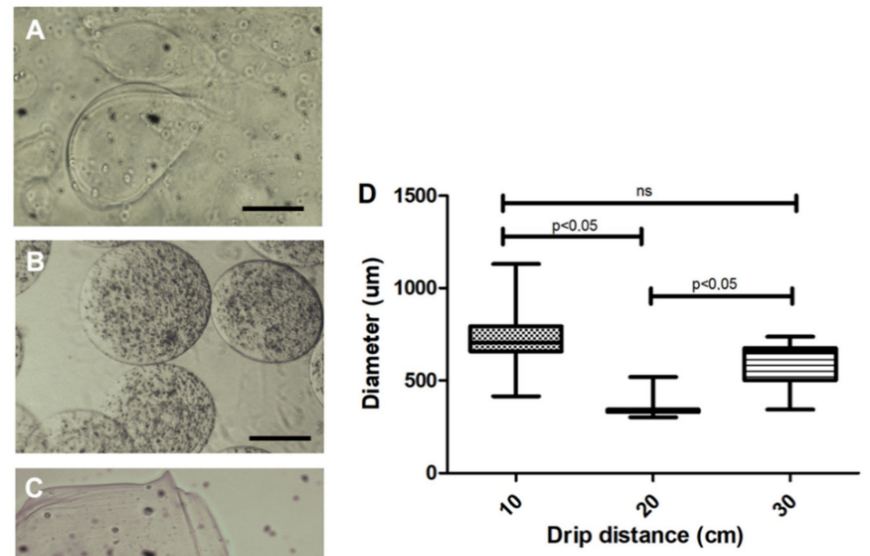

Figure 2. Effect of the microdrop distance of the 3\% sodium alginate solution on microcapsule morphology. (A) A $10 \mathrm{~cm}$ distance presented variability in shape and larger diameters $(710 \pm 135 \mu \mathrm{m})$; (B) A $20 \mathrm{~cm}$ distance presented a more homogeneous shape and smaller diameter $(364 \pm 65 \mu \mathrm{m})$; (C) A $30 \mathrm{~cm}$ distance $\mathrm{cm}$ displayed an average diameter of $593 \mu \mathrm{m}$ with more heterogeneous forms; (D) Quantification of the diameter of the capsules in relation to the distance of the drip. Photos recorded using light field optical microscope; Five independent experiments were performed in triplicate. $200 \mu \mathrm{m}$ bar. Values were considered statistically significant when $p<0.05$. ns $=$ non-significant.

Capsules at a $1 \%$ to $4 \%$ sodium alginate concentration were tested. Membrane variability was observed under a light-field and grayscale microscopic analyses (Figure 3 ). At $1 \%$ and $2 \%$ concentrations, a thinner membrane (Figure $3 \mathrm{~A}, \mathrm{~B}$ ) was observed when compared to concentrations of $3 \%$ and $4 \%$ (Figure 3C,D). The capsules produced with $4 \%$ alginate had a thicker-looking membrane when viewed under light microscopy (Figure 3C,D). Therefore, 3\% concentration was chosen for in vitro evaluations (Figure 3C). All sodium alginate concentrations were tested using the second prototype, allowing for the formation of capsules under $500 \mu \mathrm{m}$. Concerning these capsules, a significant difference between $1 \%$ and $4 \%$ concentrations was observed (Figure 3D).
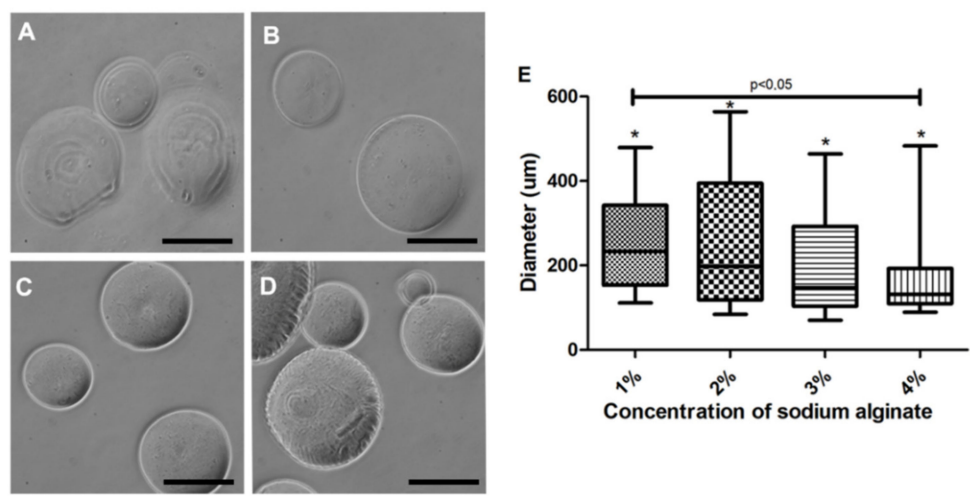

Figure 3. Morphological aspect of the microcapsules produced with the second prototype at a $20 \mathrm{~cm}$ distance. (A) $1 \%$ sodium alginate led to an altered membrane when viewed under light microscopy; (B) $2 \%$ sodium alginate presented a diameter variability $(258 \pm 154 \mu \mathrm{m})$; (C) 3\% sodium alginate produced capsules with the smoothest and most homogeneous membrane; (D) $4 \%$ sodium alginate produced smaller capsules $(166 \pm 97 \mu \mathrm{m})$ with a more heterogeneous membrane. (E) Characterization of the diameter of the capsules produced with different sodium alginate concentrations. Photos recorded using light-field microscope in gray scale (Nikon); five independent experiments were performed in triplicate. ${ }^{*}$ Values were considered statistically significant when $p<0.05$. ns $=$ non-significant. $200 \mu \mathrm{m}$ bar. 
As contact with calcium chloride is required for alginate polymerization and capsule formation, we assessed the influence of different concentrations of this solution on membrane polymerization. The capsules produced in $0.1 \mathrm{M}$ calcium chloride presented size variability (Figure $4 \mathrm{~A}$ ), with diverse forms (Figure 4B), presence of membrane artifacts (Figure 4C) and with a larger diameter $(718.5 \pm 26.87 \mu \mathrm{m})$. In contrast, $0.5 \mathrm{M}$ polymerized capsules (Figure $4 \mathrm{E}$ ) presented smoother and homogeneous forms (Figure 4D), decreased diameter $(616.9 \pm 16.21 \mu \mathrm{m})$ and remained unchanged for up to seven days in the culture medium (Figure 4E). These experimental tests were performed using the first prototype. Concerning the second prototype, diameters were greatly reduced at $0.5 \mathrm{M}$ (Figure 3E), and no significant difference between the 0.5 and $1 \mathrm{M}$ concentrations was noted.
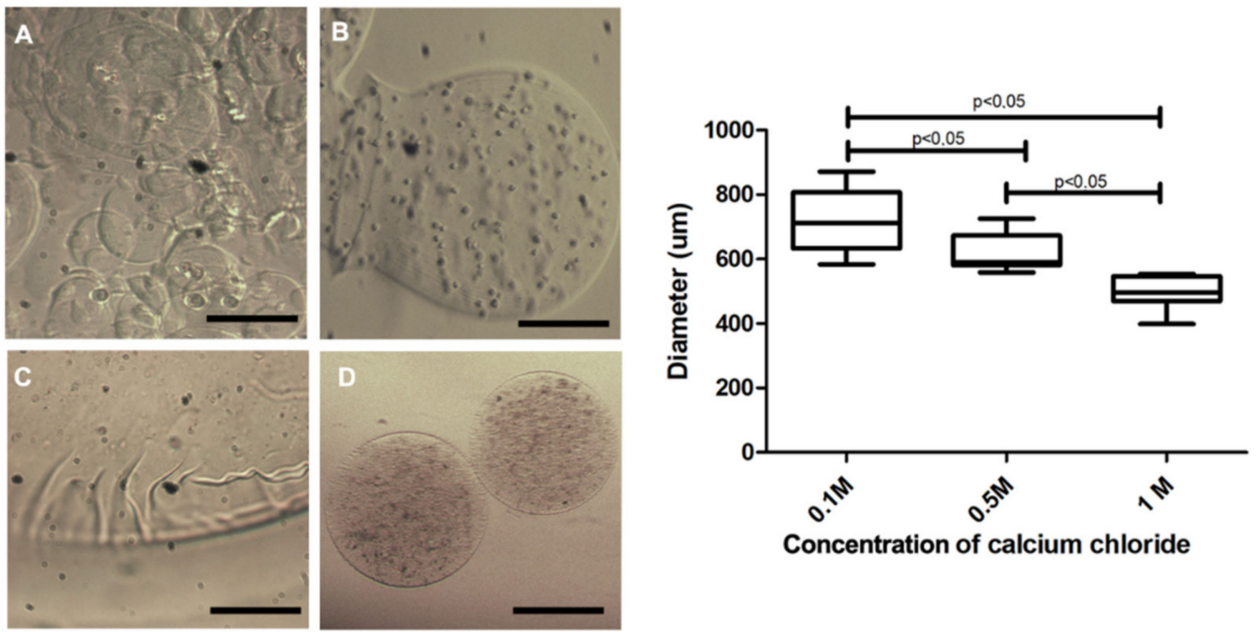

Figure 4. Capsule morphology produced with $3 \%$ sodium alginate and different calcium chloride concentrations. In (A,B), capsules polymerized in $0.1 \mathrm{M}$ calcium chloride exhibited format variability; (C) displays a representative image of the presence of artifacts in the membrane of the capsules polymerized in calcium chloride $0.1 \mathrm{M}$; (D) capsules polymerized in $0.5 \mathrm{M}$ calcium chloride, presenting a smooth membrane and diameter smaller than $0.1 \mathrm{M}$. Photos recorded using a light field microscope (Nikon); evaluation of the size of the $3 \%$ sodium alginate capsules in the polymerization process in $0.1 \mathrm{M}, 0.5 \mathrm{M}$ and 1.0 M calcium chloride. Data are plotted as mean and standard deviation. Five independent experiments were performed in triplicate using the first prototype. Values were considered statistically significant when $p<0.05 .200 \mu \mathrm{m}$ bar.

After variable evaluations and technique standardization, we performed a blind experiment with three different operators, in order to verify encapsulation technique reproducibility. Each operator performed all procedures three times on different days and the diameter count of 20 microcapsules per day was acquired (Figure 5). Although the results of the third operator were statistically different from the other operators, the diameters of the microcapsules were very similar, ranging from 400 to $650 \mu \mathrm{m}$. This slight difference may have occurred due to the lack of experience of the third operator with handling and producing microcapsules using the tested device. This factor is also important, as we have demonstrated that our device can be handled by any individual with no previous experience, which can be improved with handling time. Thus, the low-cost device is deemed simple and easy to use. 

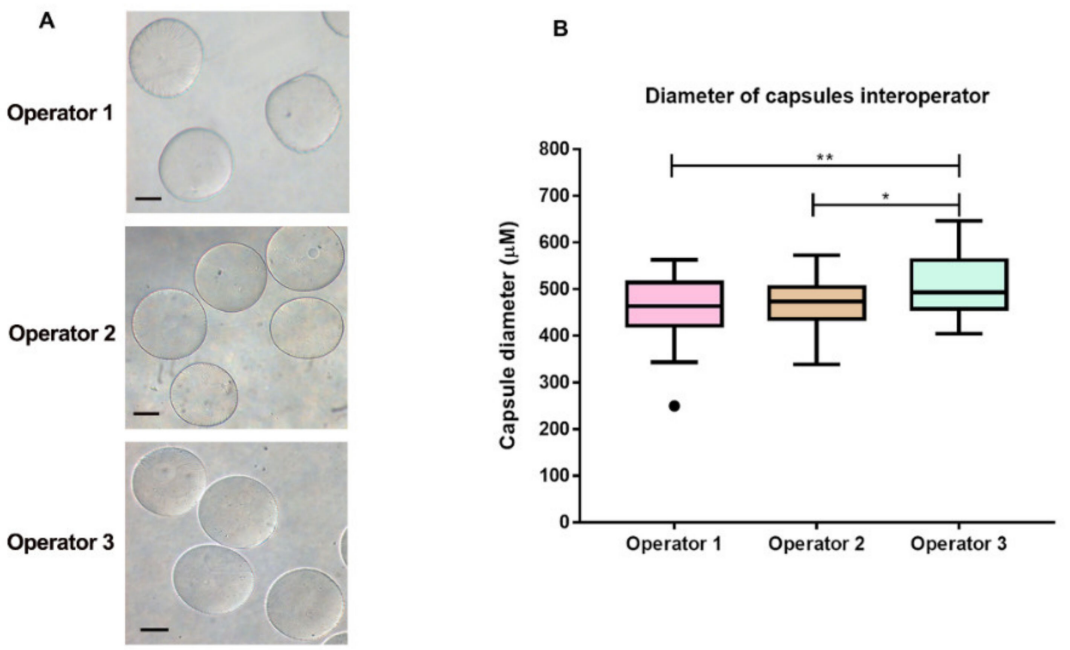

Figure 5. Reproducibility of the microcapsule production. (A) Morphological aspect of the capsules produced by the three operators in three independent experiments on different days. Scale bar presents $200 \mu \mathrm{m}$. (B) Comparative evaluation of the diameter of the capsules produced by three blind operators using the cellular encapsulation equipment printed using a 3D printer. The box plots illustrate the production of microcapsules using the low cost device by the three different operators. Reproducibility of sodium alginate microcapsule production was verified microcapsules by three independent experiments with three different operators. Each operator produced a total of 20 capsules and the diameter of each was measured. Box plot explanation: upper horizontal line of box, 75th percentile; lower horizontal line of box, 25th percentile; horizontal bar within box, median; upper horizontal bar outside box, 90th percentile; lower horizontal bar outside box, 10th percentile. Circles represent outliers. The medians significantly ${ }^{* *}=p<0.005$ and ${ }^{*}=p<0.05$.

To evaluate the cellular viability of HepG2 cells, labeling with a $2 \mu \mathrm{M}$ YO-PRO solution was carried out. Encapsulated living cells were unmarked, in contrast to the control with capsules containing dead cells (Figure 6).
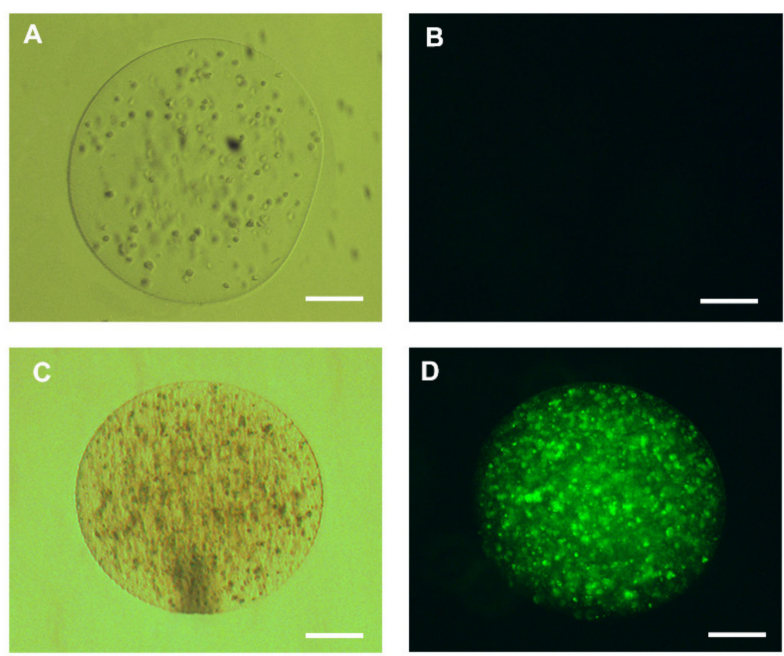

Figure 6. Representative cell viability test of human hepatocellular carcinoma cells (HepG2) cells encapsulated in 3\% sodium alginate; (A) live encapsulated hepatocytes maintained for $24 \mathrm{~h}$ in Roswell Park Memorial Institute (RPMI) medium with 10\% fetal bovine serum (FBS); (B) HepG2 cells encapsulated in $2 \mu \mathrm{M}$ YO-PRO1 solution. The living cells do not display any dye labeling, represented by the absence of fluorescence inside the capsule; (C) dead encapsulated HepG2 cells maintained for $24 \mathrm{~h}$ in RPMI medium with 10\% FBS visualized on the clear field and (D) HepG2 cells displaying fluorescence after labeling with $2 \mu \mathrm{M}$ of YO-PRO1; $200 \mu \mathrm{m}$ bar. 
In addition, we evaluated cell viability using calcein-AM and propidium iodide (IP). For this, the live HepG2 and HepG2 cells killed with detergent (5\% Tween) were encapsulated at a density of $1 \times 10^{6}$, grown with RPMI medium (Sigma Aldrish) supplemented with $10 \%$ fetal bovine serum (Sigma Aldrish) and kept in culture at $37^{\circ} \mathrm{C}, 5 \% \mathrm{CO}_{2}$ for $24 \mathrm{~h}$. Then, we incubate the cells with calcein-AM $(2 \mu \mathrm{m})$ for $30 \mathrm{~min}$, calcein-AM when hydrolyzed by intracellular esterases generates a molecule that binds to intracellular calcium resulting in a high green fluorescence, thus defining living cells present in the medium. Propidium iodide, by binding to DNA, can easily identify non-viable cells, since it is not transported by the plasma membrane; this dye can only mark DNA from broken or damaged cells in the plasma membrane. Thus, we incubate our encapsulated cells with Propidium Iodide $(1 \mu \mathrm{g} / \mathrm{mL})$ for $5 \mathrm{~min}$. For fluorescence visualization, we used the fluorescence microscope at 495/515 nm wavelength for calcein-AM and 535/617 nm for propidium iodide. In this experiment, we were able to visualize cells that were encapsulated alive by fluorescing strongly with calcein-AM and low fluorescence for propidium iodide, compared to dead encapsulated cells we can easily identify that they were not marked with calcein, but with propidium iodide after $24 \mathrm{~h}$ of cultivation (Figure 7 ). The Viability of microencased cells (HepG2) up to $72 \mathrm{~h}$ is illustrated in Supplementary Figure S3.
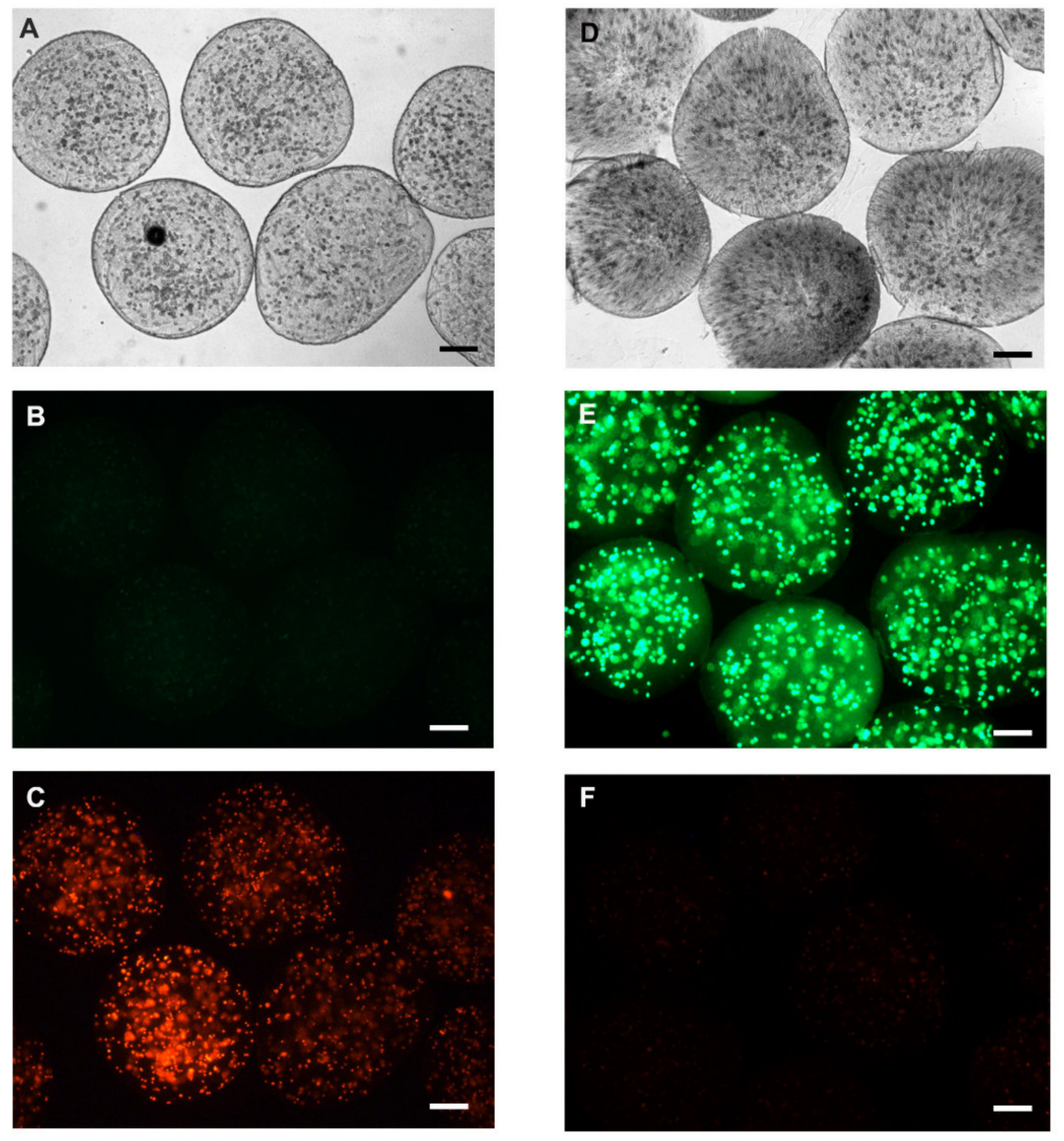

Figure 7. Representative fluorescence microscopy image with calcein-AM and propidium iodide. Initially, an assay for the negative cell viability control was performed. The cells were microencapsulated after incubation with $0.01 \%$ Triton $\mathrm{X}$ detergent for $5 \mathrm{~min}$ before encapsulation in the alginate membrane. (A) Clear field microscopy photo of dead encapsulated cells; (B) negative labeling for calcein-AM, and $(C)$ cells with positive labeling for propidium iodide. Cell viability after encapsulation was verified by encapsulating HepG2 cells with viability greater than 90\%. (D) clear field representation of cellular microencapsulation; (E) positive labeling for calcein-AM, representing cell viability after encapsulation, and (F) some cells labeled with propidium iodide. Representative photo of three experiments. Scale bar presents $100 \mu \mathrm{m}$. 


\subsection{Microcapsule Characteristics}

Microcapsules were labeled with FITC to assess membrane shape and porosity. Permeability to 20-KDa FITC-dextran was observed in capsules containing HepG2 hepatocytes (Figure 8D). For the 70-KDa FITC-dextran, decreased permeability, allowing internal cell visualization, was noted (Figure 8E). Regarding the 150-KDa FITC-dextran, no capsule permeability was observed under fluorescence microscopy (Figure $8 \mathrm{~F}$ ). This demonstrated that the alginate membrane displays porosity for components up to $70 \mathrm{KDa}$, which would allow for HepG2 cellular therapy.
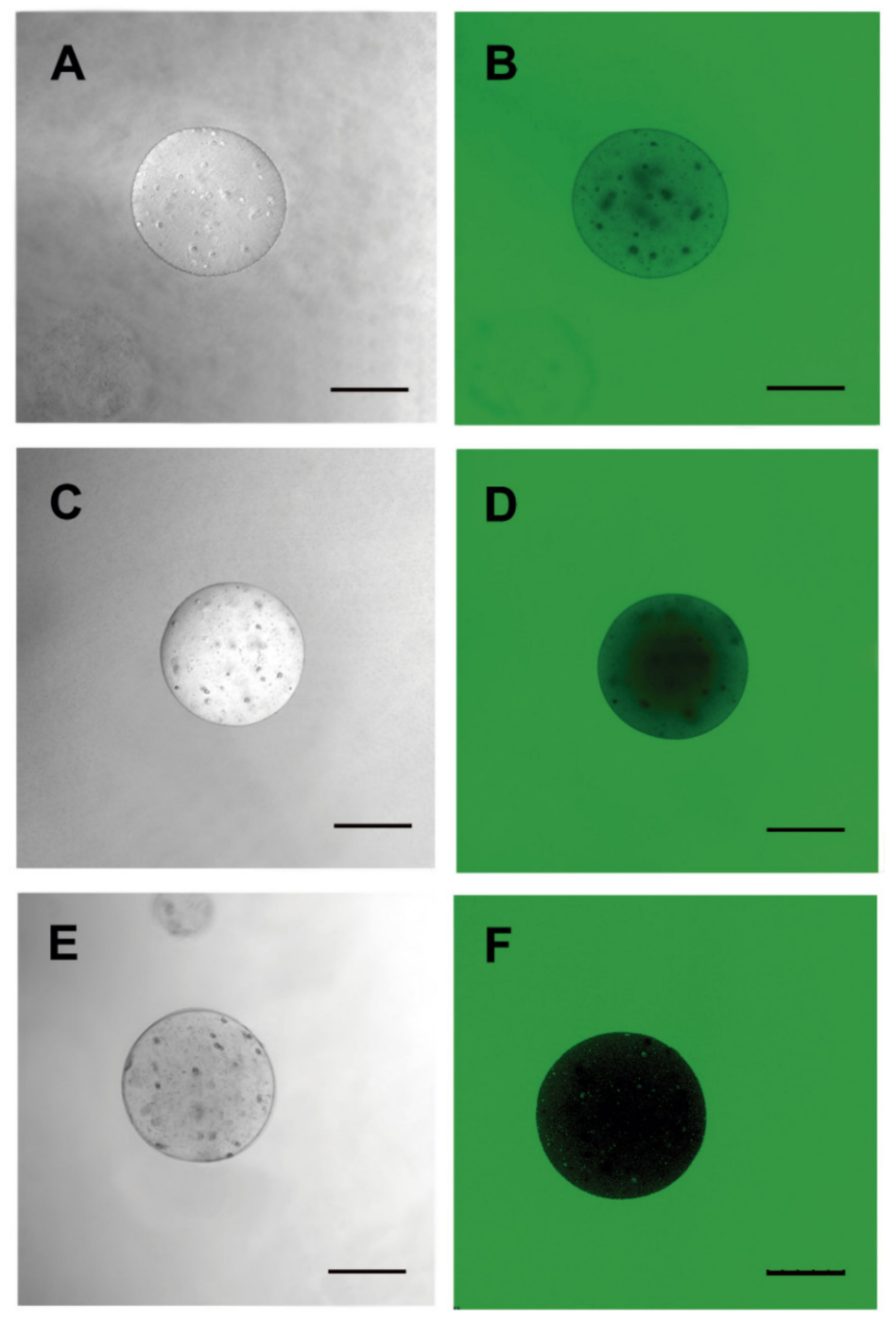

Figure 8. Porosity evaluation of the $3 \%$ sodium alginate membrane. Microcapsules containing HepG2 cells using fluorescein isothiocyanate (FITC)-dextran of different molecular weights were incubated for membrane permeability assessments. (A,D) $20 \mathrm{KDa}$; (B,E) $70 \mathrm{KDa}$ and (C,F) $150 \mathrm{KDa}$. Images were obtained by fluorescence confocal microscopy and DIC (LEICA). Three independent experiments were carried out in triplicate. Bar $250 \mu \mathrm{m}$.

\section{Discussion}

Alginate is composed of natural polymers extracted from brown algae, displaying biocompatible, biodegradable, nontoxicity and easy availability characteristics [24,27]. This polysaccharide is composed of 1,4'- $\beta$-D-mannuronic acid (M) and $\alpha$-L-guluronic acid (G) units, and simple gelation occurs when divalent cations, such as $\mathrm{Ca}^{2+}, \mathrm{Sr}^{2+}$, or $\mathrm{Ba}^{2+}$ interact with $\mathrm{G}$ monomers, forming ionic bridges between adjacent alginate chains [28]. Researchers worldwide have explored possible alginate applications 
such as coating material and applied to the preparation of controlled-release drug-delivery systems, such as microspheres, beads, pellets, gels, fibers, membranes, among others [6,24]. Alginate-based microcapsules can be coated with a permselective layer that allows for the diffusion of small molecules and proteins while also providing immune privilege by blocking antibodies and cells that contribute to immune rejection [29]. However, a persistent issue in application of alginate is the different degree of biocompatibility, which seems to be laboratory-dependent [25,30]. Different factors such as the use of different types of alginates [31], the type of coating [13] and variations in the purity of alginate have been shown to be a major cause of the variations in success of the capsules in terms of biocompatibility and acceptance by the host [25,31]. Also, items such as capsule porosity is a criteria for cell survival [32] as well as stiffness that might influence cell differentiation [33]. Purification of alginate is reported to reduce inflammatory responses against alginate based capsules but many groups have difficulties in reliably producing ultrapure alginates $[34,35]$. Another issue is that many used procedures to purify alginate have been published [36], but techniques to predict whether the purification is efficacious are lacking. In this work, the composition of the alginate that we used was approximately $61 \%$ mannuronic acid and 39\% guluronic acid. The molecular weight of this product is approximately $240 \mathrm{kDa}$, according to the manufacturer's information.

Cell microencapsulation holds promise for the treatment of many diseases by the continuous delivery of therapeutic products $[13,37]$. Clinical trials using islets encapsulated in alginate microcapsules have shown some promise as a treatment for type I diabetes $[38,39]$.

Nevertheless, there is currently a significant shortfall between the number of patients who need lifesaving transplants and the number of donated human organs. In this context, xenotransplantation addresses this relevant matter and the application of xenogeneic cells has become promising to treat several disorders, including neurodegeneration and liver failure $[37,38]$. While immunologic incompatibilities have presented a persistent impediment to their use, encapsulation may represent a way forward for the use of cell-based xenogeneic therapeutics without the need for immunosuppression [39-41].

Our device was efficient in the production of sodium-alginate capsules by the parallel air system with diameters compatible to those described in the literature, between 400 and $500 \mu \mathrm{m}$. Moreover, the porosity of the produced capsules is compatible with the passage of components up to $70 \mathrm{kDa}$ in size, allowing for proper secretion of metabolites, such as albumin and urea, in the case of employing hepatocytes. Some reports use a syringe system and different concentrations of the sodium alginate solution for microcapsule crosslinking. The diameter of the capsules produced in these studies can range from 10 to $1000 \mu \mathrm{m}$ [42-45]. However, a complete device is described herein, so that groups wishing to work with cellular microencapsulation can produce their own low-cost equipment, with reproducible results. We provide the description and measurement of each piece that makes up the device for 3D printing. In addition, we demonstrate the reproducibility of capsules with specific diameters after device manipulation by three different operators. Both microcapsule size and morphology were very similar among the operators, reinforcing the fact that our device can be manipulated by different people to obtain very close and satisfactory results.

Chantel Farias and collaborators used a microencapsulation system with parameters similar to ours to microencapsulate HepG2 cell and human glioblastoma cell (U-87) in 2018. The authors observed significant loss of viability post- $24 \mathrm{~h}$ incubation of the microencapsulated HepG2 cells, probably due to the spheroid formation detected after a day, limiting diffusion transport of oxygen and nutrients due to a stagnant microenvironment [43]. In our system, we have shown that cells remain viable $24 \mathrm{~h}$ after encapsulation, and further studies are warranted to define the viability of cells freed from the microcapsules, by approaching their ability to proliferate and differentiate.

Bressel and collaborators also developed a microencapsulation device using a parallel air system and adaptations similar to those described in this work. The group reports the optimization of a cost-benefit protocol obtaining promising results in vitro from cellular microencapsulation. Such results include maintaining viability in culture for 4 weeks without any signs of necrosis, and protein diffusion was observed during this period. In addition, encapsulated cells under the conditions described were 
able to secrete an active enzyme even after four weeks, thus becoming potentially compatible with therapeutic protein delivery [46].

Altogether, our experiments provide the basis for applying a simple and low-cost technique for cell microencapsulation, by employing a device suitable for production in 3D printers. Moreover, it further supports the use sodium alginate-based microcapsules amenable to be further assessed in cell therapy pre-clinical studies.

Supplementary Materials: The following are available online at http://www.mdpi.com/1996-1944/13/22/5090/s1. Figure S1: Cell encapsulation equipment produced in a 3D print. Measurements are displayed in millimetres $(\mathrm{mm})$ or centimetres $(\mathrm{cm})$; Figure S2: The sodium alginate microcapsules were evaluated by scanning electron microscopy-SEM (Hitachi TM 3000) fixed on carbon tapes at $5 \mathrm{kV}$, with magnification from $120 \times(\mathrm{A}), 150 \times(\mathrm{B})$ and $250 \times(\mathrm{C})$. Thus, was not possible to see the pores of the polymer; Figure S3: Viability of micro-encased cells (HepG2) up to $72 \mathrm{~h}$.

Author Contributions: M.S.P.: experimental design and execution, manuscript preparation; L.M.d.F.C.: experimental execution and manuscript design and preparation; T.B.d.S.: experimental execution; A.J.T.: experimental execution; S.E.M.: design and 3D printing encapsulation device; G.S.M.F.: design and 3D printing encapsulation device; F.M.L.D.: purification of sodium alginate; V.C.-d.-A.: preparation and revision of the manuscript and L.A.A.: concept proposal, manuscript preparation and design. All authors have read and agreed to the published version of the manuscript.

Funding: This work was supported by institutional funding from the Oswaldo Cruz Institute, Oswaldo Cruz Foundation, Rio de Janeiro State Research Council (FAPERJ), Brazilian Research Council (CNPq) Coordination for the Improvement of Higher Education Personnel (CAPES) and Mercosur Fund for Structural Convergence (FOCEM).

Acknowledgments: We wish to thank Fiocruz and to National Institute of Technology for their support of this study.

Conflicts of Interest: The authors declare no conflict of interest of any nature.

\section{References}

1. Winter, L.; Pellicer-Guridi, R.; Broche, L.; Winkler, S.A.; Reimann, H.M.; Han, H.; Arndt, F.; Hodge, R.; Günyar, S.; Moritz, M.; et al. Open Source Medical Devices for Innovation, Education and Global Health: Case Study of Open Source Magnetic Resonance Imaging. In Co-Creation; Springer: Berlin/Heidelberg, Germany, 2019.

2. Sinha, S.R.; Barry, M. Health technologies and innovation in the global health arena. N. Engl. J. Med. 2011, 365, 779-782. [CrossRef] [PubMed]

3. World Health Organization. Local Production and Technology Transfer to Increase Access to Medical Devices: Addressing the Barriers and Challenges in Low- and Middle-Income Countries. Available online: http://www.who.int/medical_devices/1240EHT_final.pdf (accessed on 24 November 2019).

4. Chang, T.M. Semipermeable Microcapsules. Science 1964, 146, 524-525. [CrossRef]

5. Lim, F.; Sun, A.M. Microencapsulated islets as bioartificial endocrine pancreas. Science 1980, $210,908-910$. [CrossRef] [PubMed]

6. Olabisi, R.M. Cell microencapsulation with synthetic polymers. J. Biomed. Mater. Res. A 2015, 103, 846-859. [CrossRef]

7. Aijaz, A.; Perera, D.; Olabisi, R.M. Polymeric Materials for Cell Microencapsulation. Methods Mol. Biol. 2017, 1479, 79-93. [CrossRef] [PubMed]

8. Prakash, S.; Jones, M.L. Artificial Cell Therapy: New Strategies for the Therapeutic Delivery of Live Bacteria. J. Biomed. Biotechnol. 2005, 2005, 44-56. [CrossRef]

9. Strand, B.L.; Gaserod, O.; Kulseng, B.; Espevik, T.; Skjak-Baek, G. Alginate-polylysine-alginate microcapsules: Effect of size reduction on capsule properties. J. Microencapsul. 2002, 19, 615-630. [CrossRef]

10. Robitaille, R.; Pariseau, J.F.; Leblond, F.A.; Lamoureux, M.; Lepage, Y.; Halle, J.P. Studies on small $(<350 \mu \mathrm{m})$ alginate-poly-L-lysine microcapsules. III. Biocompatibility Of smaller versus standard microcapsules. J. Biomed. Mater. Res. 1999, 44, 116-120. [CrossRef]

11. Risbud, M.V.; Shapiro, I.M.; Vaccaro, A.R.; Albert, T.J. Stem cell regeneration of the nucleus pulposus. Spine J. Off. J. N. Am. Spine Soc. 2004, 4, 348S-353S. [CrossRef] 
12. Yang, Y.; Opara, E.C.; Liu, Y.; Atala, A.; Zhao, W. Microencapsulation of porcine thyroid cell organoids within a polymer microcapsule construct. Exp. Biol. Med. 2017, 242, 286-296. [CrossRef]

13. Orive, G.; Santos, E.; Pedraz, J.L.; Hernandez, R.M. Application of cell encapsulation for controlled delivery of biological therapeutics. Adv. Drug Deliv. Rev. 2014, 67-68, 3-14. [CrossRef] [PubMed]

14. Farina, M.; Alexander, J.F.; Thekkedath, U.; Ferrari, M.; Grattoni, A. Cell encapsulation: Overcoming barriers in cell transplantation in diabetes and beyond. Adv. Drug Deliv. Rev. 2019, 139, 92-115. [CrossRef]

15. Zhang, H.; Zhu, S.J.; Wang, W.; Wei, Y.J.; Hu, S.S. Transplantation of microencapsulated genetically modified xenogeneic cells augments angiogenesis and improves heart function. Gene Ther. 2008, 15, 40-48. [CrossRef] [PubMed]

16. Zhang, W.; Ouyang, H.; Dass, C.R.; Xu, J. Current research on pharmacologic and regenerative therapies for osteoarthritis. Bone Res. 2016, 4, 15040. [CrossRef] [PubMed]

17. Fastag, E.; Varon, J.; Sternbach, G. Richard Lower: The origins of blood transfusion. J. Emerg. Med. 2013, 44, 1146-1150. [CrossRef] [PubMed]

18. Shapiro, A.M.; Pokrywczynska, M.; Ricordi, C. Clinical pancreatic islet transplantation. Nat. Rev. Endocrinol. 2017, 13, 268-277. [CrossRef] [PubMed]

19. Bryant, S.J.; Anseth, K.S. Hydrogel properties influence ECM production by chondrocytes photoencapsulated in poly(ethylene glycol) hydrogels. J. Biomed. Mater. Res. 2002, 59, 63-72. [CrossRef] [PubMed]

20. Tibbitt, M.W.; Anseth, K.S. Hydrogels as extracellular matrix mimics for 3D cell culture. Biotechnol. Bioeng. 2009, 103, 655-663. [CrossRef]

21. Luca, G.; Cameron, D.F.; Arato, I.; Mancuso, F.; Linden, E.H.; Calvitti, M.; Falabella, G.; Szekeres, K.; Bodo, M.; Ricci, G.; et al. Xenograft of microencapsulated Sertoli cells for the cell therapy of type 2 diabetes mellitus in spontaneously diabetic nonhuman primates: Preliminary data. Transpl. Proc. 2014, 46, 1999-2001. [CrossRef]

22. Calafiore, R. Microencapsulation for cell therapy of type 1 diabetes mellitus: The interplay between common beliefs, prejudices and real progress. J. Diabetes Investig. 2018, 9, 231-233. [CrossRef]

23. Omami, M.; McGarrigle, J.J.; Reedy, M.; Isa, D.; Ghani, S.; Marchese, E.; Bochenek, M.A.; Longi, M.; Xing, Y.; Joshi, I.; et al. Islet Microencapsulation: Strategies and Clinical Status in Diabetes. Curr. Diabetes Rep. 2017, 17, 47. [CrossRef] [PubMed]

24. Lee, K.Y.; Mooney, D.J. Alginate: Properties and biomedical applications. Prog. Polym. Sci. 2012, 37, $106-126$. [CrossRef] [PubMed]

25. De Vos, P.; De Haan, B.; Van Schilfgaarde, R. Effect of the alginate composition on the biocompatibility of alginate-polylysine microcapsules. Biomaterials 1997, 18, 273-278. [CrossRef]

26. Orive, G.; Ponce, S.; Hernandez, R.M.; Gascon, A.R.; Igartua, M.; Pedraz, J.L. Biocompatibility of microcapsules for cell immobilization elaborated with different type of alginates. Biomaterials 2002, 23, 3825-3831. [CrossRef]

27. Santos, E.; Zarate, J.; Orive, G.; Hernandez, R.M.; Pedraz, J.L. Biomaterials in cell microencapsulation. Adv. Exp. Med. Biol. 2010, 670, 5-21. [PubMed]

28. Amsden, B.; Turner, N. Diffusion characteristics of calcium alginate gels. Biotechnol. Bioeng. 1999, 65, 605-610. [CrossRef]

29. Kong, H.J.; Smith, M.K.; Mooney, D.J. Designing alginate hydrogels to maintain viability of immobilized cells. Biomaterials 2003, 24, 4023-4029. [CrossRef]

30. Tam, S.K.; Bilodeau, S.; Dusseault, J.; Langlois, G.; Halle, J.P.; Yahia, L.H. Biocompatibility and physicochemical characteristics of alginate-polycation microcapsules. Acta Biomater. 2011, 7, 1683-1692. [CrossRef]

31. De Vos, P.; Bucko, M.; Gemeiner, P.; Navratil, M.; Svitel, J.; Faas, M.; Strand, B.L.; Skjak-Braek, G.; Morch, Y.A.; Vikartovska, A.; et al. Multiscale requirements for bioencapsulation in medicine and biotechnology. Biomaterials 2009, 30, 2559-2570. [CrossRef]

32. Vaithilingam, V.; Quayum, N.; Joglekar, M.V.; Jensen, J.; Hardikar, A.A.; Oberholzer, J.; Guillemin, G.J.; Tuch, B.E. Effect of alginate encapsulation on the cellular transcriptome of human islets. Biomaterials 2011, 32, 8416-8425. [CrossRef]

33. Li, X.; Liu, T.; Song, K.; Yao, L.; Ge, D.; Bao, C.; Ma, X.; Cui, Z. Culture of neural stem cells in calcium alginate beads. Biotechnol. Prog. 2006, 22, 1683-1689. [CrossRef] [PubMed]

34. Orive, G.; Tam, S.K.; Pedraz, J.L.; Halle, J.P. Biocompatibility of alginate-poly-L-lysine microcapsules for cell therapy. Biomaterials 2006, 27, 3691-3700. [CrossRef] [PubMed]

35. De Vos, P.; Faas, M.M.; Strand, B.; Calafiore, R. Alginate-based microcapsules for immunoisolation of pancreatic islets. Biomaterials 2006, 27, 5603-5617. [CrossRef] [PubMed] 
36. Dusseault, J.; Tam, S.K.; Menard, M.; Polizu, S.; Jourdan, G.; Yahia, L.; Halle, J.P. Evaluation of alginate purification methods: Effect on polyphenol, endotoxin, and protein contamination. J. Biomed. Mater. Res. A 2006, 76, 243-251. [CrossRef] [PubMed]

37. Murua, A.; Portero, A.; Orive, G.; Hernandez, R.M.; de Castro, M.; Pedraz, J.L. Cell microencapsulation technology: Towards clinical application. J. Control. Release 2008, 132, 76-83. [CrossRef]

38. Barkai, U.; Rotem, A.; de Vos, P. Survival of encapsulated islets: More than a membrane story. World J. Transpl. 2016, 6, 69-90. [CrossRef]

39. Sakata, N.; Sumi, S.; Yoshimatsu, G.; Goto, M.; Egawa, S.; Unno, M. Encapsulated islets transplantation: Past, present and future. World J. Gastrointest. Pathophysiol. 2012, 3, 19-26. [CrossRef]

40. Aebischer, P.; Buchser, E.; Joseph, J.M.; Favre, J.; de Tribolet, N.; Lysaght, M.; Rudnick, S.; Goddard, M. Transplantation in humans of encapsulated xenogeneic cells without immunosuppression. A preliminary report. Transplantation 1994, 58, 1275-1277. [CrossRef]

41. Bes, J.C.; Lazorthes, Y.; Sol, J.C.; Tkaczuk, J.; Sallerin, B. Clinical perspectives of xenografts: Encapsulated chromaffin cells and pain. Pathol. Biol. 2000, 48, 365-367.

42. Etter, J.N.; Karasinski, M.; Ware, J.; Oldinski, R.A. Dual-crosslinked homogeneous alginate microspheres for mesenchymal stem cell encapsulation. J. Mater. Sci. Mater. Med. 2018, 29, 143. [CrossRef]

43. Farias, C.; Lyman, R.; Hemingway, C.; Chau, H.; Mahacek, A.; Bouzos, E.; Mobed-Miremadi, M. Three-Dimensional (3D) Printed Microneedles for Microencapsulated Cell Extrusion. Bioengineering 2018, 5, 59. [CrossRef] [PubMed]

44. Mobed-Miremadi, M.; Asi, B.; Parasseril, J.; Wong, E.; Tat, M.; Shan, Y. Comparative diffusivity measurements for alginate-based atomized and inkjet-bioprinted artificial cells using fluorescence microscopy. Artif. Cells Nanomed. Biotechnol. 2013, 41, 196-201. [CrossRef] [PubMed]

45. Sugiura, S.; Oda, T.; Aoyagi, Y.; Matsuo, R.; Enomoto, T.; Matsumoto, K.; Nakamura, T.; Satake, M.; Ochiai, A.; Ohkohchi, N.; et al. Microfabricated airflow nozzle for microencapsulation of living cells into 150 micrometer microcapsules. Biomed. Microdevices 2007, 9, 91-99. [CrossRef] [PubMed]

46. Bressel, T.A.; Paz, A.H.; Baldo, G.; Lima, E.O.C.; Matte, U.; Saraiva-Pereira, M.L. An effective device for generating alginate microcapsules. Genet. Mol. Biol. 2008, 31, 136-140. [CrossRef]

(C) 2020 by the authors. Licensee MDPI, Basel, Switzerland. This article is an open access article distributed under the terms and conditions of the Creative Commons Attribution (CC BY) license (http://creativecommons.org/licenses/by/4.0/). 